\title{
Uma abordagem descolonial sobre de- mocracia e cultura jurídica na modernidade
}

\author{
A decolonial approach on democracy and \\ legal culture in modernity
}

\author{
Antonio Carlos Wolkmer ${ }^{1}$ \\ Débora Ferrazzo 2
}

Resumo: A democracia representativa é um dos paradigmas da modernidade, manifesto no campo da política e do direito. Assim como ocorreu nos demais campos da ciência, por meio da dissimulação de sua relação com uma cultura jurídica específica, a europeia moderna, esse modelo alcançou a abstração necessária para impor-se como modelo universal e colonizar os processos políticos dos países periféricos, nos quais os sistemas jurídicos implantados favoreceram a difusão da democracia representativa, mediante a subalterni-

1 Professor Permanente do Mestrado em Direito e Sociedade da UNILASSALLE-RS e do Mestrado em Direitos Humanos da UNESC-SC. Professor Titular Aposentado no Programa de Pós-Graduação em Direito da Universidade Federal de Santa Catarina. Doutor em Direito.

2 Doutoranda em Direito pela Universidade Federal do Paraná (UFPR); Mestra em Direito pela Universidade Federal de Santa Catarina (UFSC). Professora no Curso de Direito da Universidade do Extremo Sul Catarinense (UNESC). Pesquisadora no Grupo de Pesquisas em Pensamento Jurídico Crítico Latino-americano (UNESC). 
zação ou criminalização de práticas originárias. Contudo, tais práticas nunca foram totalmente suprimidas, como evidenciaram os últimos processos constituintes de países como Bolívia e Venezuela. Tais experiências revelam os limites do eurocentrismo na compreensão da realidade e reivindicam epistemologias descoloniais que permitam questionar os cânones colonizadores e reconhecer novos paradigmas, como a democracia comunitária ou a democracia comunal, sendo ambos evidência da possibilidade de normatividades insurgentes desde o continente latino-americano. Mediante uma abordagem interdisciplinar, buscar-se-á refletir esse tema a partir de abordagens críticas e descoloniais, questionando a abstração do modelo jurídico-político e sugerindo que outros modelos são, não apenas possíveis, mas necessários.

Palavras-chave: cultura jurídica; paradigmas eurocêntricos; descolonização; sistemas democráticos;

Abstract: The representative democracy is one of the paradigms of modernity that manifests in the field of politics and law. As in other scientific fields, by dissimulating their connection with a specific legal culture, the modern European model reached abstraction level necessary to impose itself as a universal standard and to colonize the political processes of the peripheral countries. The juridical systems established in these countries favored the diffusion of representative democracy, criminalizing traditional practices, however, unable to suppress them, as evidenced in the recent constituent processes of Bolivia and Venezuela. Such experiences reveal the limits of Eurocentrism in the understanding of reality and claim decolonial epistemologies that allow to question the colonizing canons and to recognize new paradigms, such as community democracy 
or communal democracy, both indications of the possibility of insurgents normativities in the Latin American continent.

Keywords: legal culture; eurocentric paradigms; decolonization; democratic systems.

\section{Introdução}

Contemporaneamente verificam-se no campo das ciências alguns pressupostos, conceitos e modelos que são assumidos como universais, referenciais adotados para avaliar e mensurar o desenvolvimento de seus respectivos campos teóricos. São os paradigmas da modernidade. No campo da política, tal modelo está conformado sobre as bases da democracia, especificamente, na sua forma representativa. Assim como os demais paradigmas, a democracia representativa é presumida como a forma ideal de organização de processos políticos, sendo adotada como um dos indicadores de desenvolvimento, na análise das mais distintas sociedades. Mas a universalização exige que o modelo alcance um nível de abstração que o destitua completamente de sua conexão com realidades específicas. No caso da democracia representativa, tem-se um modelo construído a partir de uma cultura específica, mas ideologicamente abstraído dela. As ideologias, tomadas em sua acepção crítica (marxista), negam aos cânones contemporâneos, inclusive à democracia representativa, o ponto de partida culturalmente definido que lhes integram e tal negação é necessária para não comprometer a aspiração de universalidade própria das ciências hegemônicas. Por isso, operou-se uma dicotomia entre cultura e ciências, como se ambas fossem incompatíveis, quando na verdade, são dimensões imbricadas na composição do pensamento e da própria racionalidade moderna. 
Os modelos hegemônicos, adotando aqui a definição de Gramsci, impõe-se desde o centro em que são concebidos precipuamente a Europa, mas também os Estados Unidos da América - até as periferias, nelas incluída a América Latina. Delimitando a problematização no campo dos processos políticos e sistemas jurídicos, projeta-se uma expectativa de que os modelos representativos devem ser seguidos como a única alternativa viável para concretizar uma genuína democracia. Como as tradições pré-coloniais desenvolviam processos distintos daqueles concebidos no curso da história europeia, a partir da colonização e conquista, passa a se operar uma sobreposição do modelo colonizador perante os modelos originários, culminando na homogeneização das instituições democráticas latino-americanas. Os sistemas jurídicos implantados nesses países garantem a eficácia da difusão dos modelos externos mediante a subalternização ou criminalização das práticas originárias. Mas em que pese o encobrimento das formas ancestrais, tais formas nunca são definitivamente erradicadas, de modo que, nos últimos anos, ressurgem como potência constituinte nas pautas políticas de muitos desses países da região andina e especialmente no que se refere ao constitucionalismo, na Bolívia e na Venezuela.

A luta pelo reconhecimento das formas ancestrais de organizar a vida pública é uma reivindicação complexa, pois é pressuposto para o desenvolvimento e continuidade de suas longas tradições, de suas racionalidades, em suma, de suas culturas. Por isso, os processos políticos de insurgência popular significam a abertura epistemológica para inclusão de outros paradigmas na pauta global, uma inclusão sem reduzir a distinção periférica à totalidade eurocêntrica, como vinha ocorrendo desde a conquista da América e como pontuam autores como Enrique Dussel e no campo da jusfilosofia brasileira, Celso Ludwig, conforme será exposto 
no desenvolvimento dessas reflexões. A diferença das reivindicações epistemológicas descoloniais é que não aspiram a universalidade, mas buscam a quebra dos monismos, dos monopólios científicos e culturais estabelecidos nos últimos séculos, colonizando o saber, o ser e o poder no Ocidente.

As lutas populares e os últimos processos constituintes latino-americanos, dos quais, aqui se enfatizam o venezuelano e o boliviano, desafiam os modelos eurocêntricos e reivindicam a emergência de novas epistemologias. Os paradigmas eurocêntricos, em especial monismo jurídico e democracia representativa, negam às experiências periféricas acesso ao campo das validações científicas, de modo que, em seus termos, não é possível reconhecer, tampouco compreender, as conquistas sociais ocorridas nos últimos anos na América latina. Portanto, pretende-se apresentar uma abordagem descolonial acerca da relação entre democracia e cultura e da normatividade que contribui na dissimulação dessa relação, porque as reflexões predominantes nos campos da filosofia política e da teoria do direito, ao universalizarem o paradigma democrático, abstraem um modelo que é, na realidade, culturalmente definido.

É com essa preocupação que se adotará uma abordagem interdisciplinar, não somente como questionamento à compartimentalização cartesiana do saber, mas principalmente porque a complexidade do tema não pode ser enfrentada sem uma interpretação crítica apoiada no aporte de várias disciplinas. Trata-se, inicialmente, de problematizar a abstração do paradigma democrático adotado na modernidade, por meio da negação de sua conexão cultural, bem como, refletir a respeito das implicações de tal abstração no campo da normatividade. Na obra de Enrique Dussel recorre-se a alguns elementos teóricos para fundamentar as proposições da primeira seção. Já na segunda, pretende- 
-se refletir sobre dois processos de transição política que estão em curso na América Latina: a constitucionalização da democracia comunitária na Bolívia e o desenvolvimento infraconstitucional - a partir de bases constitucionais - da democracia comunal na Venezuela. Pretende-se com isso identificar elementos de similaridade e distinção entre essas experiências, suas contradições e desafios, pois acredita-se que algumas controvérsias que envolvem os temas podem ser atribuídas à hegemonia da democracia representativa e à resistência das forças políticas conservadoras em ambos os cenários. Na última seção, serão comparados dados quantitativos de opinião pública coletados em países latino-americanos, cuja interpretação evidenciará que os índices mais elevados de legitimação democrática são verificados nos países que desenvolveram novas instituições e processos jurídico-políticos. Isso permitirá o estranhamento da democracia representativa, revelando também, a possibilidade de normatividades insurgentes no continente.

\section{Democracia representativa e a pretensão normativa de universalidade da cultura ju- rídica europeia}

A categoria pretensão por si só não assume implicações coloniais. Tal ideia é encontrada inclusive em autores do campo teórico descolonial, como Enrique Dussel ${ }^{3}$, que emprega o termo de modo a indicar sua constante abertura à reflexão, bem como demonstrar o reconhecimento de que suas teses pretendem algo, mas não prescrevem algo. No desenvolvimento da racionalidade moderna por outro lado, a pretensão à universalidade significou a prescrição de uma série

3 DUSSEL, 2012. 
de modelos ideais a serem reproduzidos pelas sociedades que aspirassem a condição de modernas, desenvolvidas ou civilizadas. Cada campo do conhecimento assumiu seu conjunto próprio de paradigmas. Para Celso Ludwig, o paradigma consiste "num modelo de racionalidade, num padrão teórico, hegemônico em determinados momentos da história, e aceito pela comunidade que o utiliza como fundamento do saber na busca de compreensões e soluções" ${ }^{4}$. Os modelos hegemônicos da modernidade originam-se do monopólio do desenvolvimento da ciência, exercido nos últimos séculos pelos países europeus e norte-americanos, como parte de um fenômeno designado eurocentrismo. Conforme Cárdenas et al. ${ }^{5}$, a cultura jurídica europeia coloca a Europa não apenas como espaço físico, mas também como "figura dominante" na identificação e reconhecimento de outras experiências e assim vai permeando distintas realidades, com a difusão de seus próprios modelos e processos.

Esses paradigmas, e aqui a ênfase recai sobre o da representação política, sustentados como horizontes universais, exigem um nível de abstração que contraria a realidade, pois, os paradigmas modernos são produto de uma cultura específica, de um contexto real que a abstração intenta negar. Por isso se diz que os paradigmas da modernidade dissimulam sua origem. Conforme define Baudrillard6, "Dissimular é fingir não ter o que se tem". É o que ocorre com a democracia. Os processos políticos reconhecidos nos sistemas jurídicos contemporaneamente são resultado de um contexto cultural específico: o triunfo das revoluções burguesas na Europa e Estados Unidos. Para a universalização e consolidação do paradigma, entretanto, dissimula-se a conexão entre de-

\footnotetext{
4 LUDWIG, 2006, p. 26.

5 CARDENAS et al., 2016, p. 84.

6 BAUDRILLARD, 1991, p. 9.
} 
mocracia representativa e a cultura jurídica europeia. Uma conexão que se pretende demonstrar, iniciando com a problematização da ideia de cultura. Num sentido mais amplo, cultura pode ser definida como

[...] o conjunto orgânico de comportamentos predeterminados por atitudes diante dos instrumentos de civilização, cujo conteúdo teleológico é constituído pelos valores e símbolos do grupo, isto é, estilos de vida que se manifestam em obras de cultura e que transformam o âmbito físico-animal em um mundo humano, um mundo cultural. ${ }^{7}$

Cultura é um conceito com complexidade semântica que causa perplexidade na comunidade teórica. Acompanhando a definição de Dussel, verifica-se que na América Latina a questão se mostra ainda mais delicada, já que "A cultura e a civilização americanas não são pré-hispânicas, mas aquela que lenta e sincreticamente foi se construindo depois" $^{\prime \prime}$. E a cultura no continente vai se formando a partir da sobreposição de valores e símbolos provenientes de contextos ("estilos de vida") bastante distintos, até culminar no estágio atual, onde se constata a reprodução de modelos colonizadores coexistindo com racionalidades de resistência que fundamentam sua organização coletiva em modelos ancestrais, muitos desses, pré-coloniais. Um desses modelos é a democracia e o sentido desse conceito é igualmente polissêmico, pois integra uma das dimensões do "mundo cultural".

Existe uma concepção hegemônica ${ }^{9}$ acerca da democracia no ocidente moderno, uma concepção que se situa nos

7 DUSSEL, 1997, p. 34. Grifo no original

8 DUSSEL, 1997, p. 19-20.

9 O sentido de hegemonia é buscado na obra do italiano Antonio Gramsci, que identifica a função de hegemonia que um grupo dominante exerce sobre toda a sociedade. O grupo dominante exerce seu comando através 
contornos de uma teoria política igualmente hegemônica: seguindo um desenvolvimento científico que integra o que Grosfoguel ${ }^{10}$ define como "paradigmas eurocêntricos hegemônicos que ao longo dos últimos quinhentos anos inspiraram a filosofia e as ciências ocidentais do 'sistema-mundo patriarcal/capitalista/ colonial/moderno". E conclui que tais paradigmas se apresentam como neutros e universalmente válidos. Para Dussel ${ }^{11}$ a ciência, em especial a que se pretende universal, é o mais sutil instrumento de dominação. Ressalta que não há, de fato, uma ciência universal, pois as escolhas pré-científicas, que lhe são essenciais, são política, cultural, humanamente definidas. Por isso, existe um condicionamento político sobre a ciência. Antes da ciência vem o mundo cotidiano e depois da ciência o projeto: a ciência está entre o cotidiano e o projeto. Portanto, é o mundo cotidiano de determinada época e lugar que dá o projeto à ciência.

No âmbito da teoria política - e da democracia especificamente - verifica-se contemporaneamente uma grande dificuldade em conceber modelos distintos àqueles desenvol-

do Estado e do governo "jurídico" e tem nos intelectuais seus "prepostos": aqueles que exercem as funções subalternas da "hegemonia social e do governo político": contribuem para o consenso "espontâneo" entre as grandes massas seguindo a orientação do grupo dominante no que se refere à vida social e na fundamentação da coerção estatal exercida legalmente para disciplinar aqueles que não consentem, sendo tal coerção estendida para toda a sociedade nos momentos de crise, quando o consenso espontâneo desaparece (GAMSCI, 2001, p. 20-21). Em suma, a hegemonia se traduz na capacidade de direção intelectual exercida pelos "aparatos hegemônicos" das classes em ascensão como um dos elementos pelos quais uma classe alcança a supremacia, obtendo o consenso das classes aliadas e subalternas (ABBAGNANO, 2007, p. 578). Nesse caso específico, a democracia representativa é um modelo que se concretiza por meio das lutas revolucionárias da classe burguesa, empreendidas nos séculos XVI e XVII, cuja hegemonia teórica subsiste até os dias atuais junto à hegemonia de classe.

10 GROSFOGUEL, 2010, p. 458.

11 DUSSEL, 1997, p. 140. 
vidos pela tradição grega clássica e, posteriormente, a partir da experiencia iluminista. Em ambos os casos se verifica que

A democracia no Ocidente desenvolveu-se historicamente como um sistema de legitimação dos interesses dominantes em cada época, realidade agravada com o advento da economia capitalista de mercado, que conduziu a democracia a uma profunda crise. ${ }^{12}$

Tal crise, Wolkmer ${ }^{13}$ associa aos valores hegemônicos do Estado-nação e suas funções tradicionais, cada vez mais desacreditadas perante a legitimação popular. Nesse contexto de crise, fica evidente a insuficiência da democracia representativa e do suposto "pensamento único". Esse fenômeno, globalmente sentido, assume contornos peculiares na periferia latino-americana, já que, conforme analisa o autor, a democracia concretizada no continente não é genuinamente representativa, mas sim, um arranjo manipulado pelas elites, e a isso se acrescenta que a cultura política local se desenvolveu marcada por especificidades como exclusão, clientelismo e ausência de participação. ${ }^{14}$

Como que alheias à questão do esgotamento do paradigma democrático e do monismo jurídico, as academias reproduzem cientifica e retoricamente tais modelos e, mesmo as abordagens críticas que aspiram a superação das relações de dominação de classe, raramente contemplam discursos e modelos originados fora do eixo norte-eurocêntrico. Nos diversos cursos de graduação, as disciplinas do campo da ciência política e da teoria geral do Estado costumam lecionar basicamente os mesmos conteúdos, como se nota no cotejamento dos cursos "mais populares", a exemplo, a Teoria

12 WOLKMER; FERRAZZO, 2014, p. 200.

13 WOLKMER, 2003.

14 Por outro lado, a crise da democracia também provocou o questionamento e ruptura frente aos paradigmas liberais, pilares da "visão tradicional homogeneizante", a partir do que, saberes historicamente subalternizados vêm sendo recuperados (ZEGADA C., 2017, p. 571-572) 
das Formas de Governo de Norberto Bobbio ${ }^{15}$ em que o autor percorre algumas teorias que considera mais conhecidas sobre formas de governo e parte dos pensadores gregos para chegar aos europeus modernos, como os iluministas, Hegel e Marx. Finalmente, quando a América Latina aparece na obra, "entra pela porta dos fundos", no capítulo final reservado às ditaduras, onde o General Pinochet ocupa merecido lugar. Semelhante é o percurso teórico realizado por Luciano Grup$\mathrm{pi}^{\mathbf{1 6}}$, naturalmente sob a influência dos estudos realizados em Marx e Gramsci, mas igualmente circunscrito ao pensamento europeu moderno, de modo que sua crítica se concentra na disputa entre proletariado e burguesia, sublinhando o potencial revolucionário do primeiro. Outra obra muito popular, Os clássicos da política, organizada por Francisco Weffort ${ }^{17}$ reúne contribuições que resenham basicamente os mesmos autores que integram os títulos já mencionados (Maquiavel, Hobbes, Locke, Montesquieu entre outros). Tais exemplos demonstram como a ciência política difunde e reproduz nas academias brasileiras modelos hegemônicos e externos.

A concepção hegemônica que vigora no ocidente a respeito da democracia entende tal sistema como a soberania do povo, uma soberania que pode ser exercida diretamente, tal como se deu na experiência ateniense das assembleias e que nos últimos séculos foi reduzida à possibilidade de plebiscitos, referendos e iniciativas populares, ou pode ser exercida por meio dos representantes para tal fim designados. Em geral, essas são as modalidades transpostas e regulamentadas pelos sistemas jurídicos ocidentais, como é o caso verificado na constituição brasileira de 1988. A normatividade estatal é uma das formas pelas quais a força prescritiva do paradigma

\footnotetext{
15 BOBBIO, 1998.

16 GRUPPI, 1996.

17 WEFFORT, 2011.
} 
democrático se manifesta, a formalidade na qual assume coercitividade jurídica.

Um artigo publicado por Przeworski, Cheibub e Limongi, em 2003, propõe-se a discutir a relação entre democracia e cultura para argumentar em favor de uma visão não culturalista do tema. Os autores reconhecem a dificuldade de delimitar o sentido de "cultura", mas, paradoxalmente, assumem "democracia" como um conceito dado, dogmatizando-o, como se não comportasse uma forte dimensão polissêmica e assim, não delimitam seu sentido, mas presumem-no na forma da democracia representativa. Eis aqui uma contradição: presumir um sentido a priori para democracia é uma escolha pré-científica, como explica Dussel ${ }^{18}$, definida não pela ciência, mas pelo entorno do cientista, por aquilo que lhe é cotidiano, por isso, suas escolhas são empregadas como axiomas, mas ignorando que os axiomas também são culturalmente definidos. Veja-se.

Para Przeworski, Cheibub e Limongi ${ }^{19}$ não é a cultura de uma sociedade, mas sim fatores econômicos e institucionais que determinam a dinâmica da democracia. Para sustentar sua posição, citam diversos estudos que se propõe a pensar a questão, mas todos assumem um ponto de partida, que é seu mesmo horizonte: modelos de democracia representativa e, em alguns casos, experiências específicas consideradas paradigmáticas, como a cultura cívica estado-unidense. Em outros casos, mencionam modelos de democracia consideradas instáveis a luz do modelo ideal adotado como referência, nomeadamente, as democracias latino-americanas. E alguns dos estudos que os autores citam chegam mesmo a concluir que a cultura latino-americana é incompatível com a democracia, como os de Howard Wiarda,

18 DUSSEL, 1997, p. 140.

19 PRZEWORSKI, CHEIBUB; LIMONGI, 2003. 
publicados nos anos 1980 e resgatados para ilustrar algumas posições culturalistas. De qualquer modo, na sua pretensão de objetividade cientifica, os autores concluem que as visões culturalistas não podem ser testadas na maioria dos países, mas a visão não culturalista pode.

A argumentação Przeworski, Cheibub e Limongi ${ }^{20}$ sustenta haver apoio empírico para a concepção não culturalista. Nessa concepção, a sobrevivência da democracia estaria relacionada às vantagens que as forças políticas - vencedoras ou não - obteriam respeitando os resultados das urnas. Além disso, o aumento da renda também é considerado favorável para a persistência da democracia, do mesmo modo que países pobres se mostram vulneráveis, do ponto de vista democrático, a crises econômicas. Na verdade, as conclusões são extraídas de estudos e estatísticas obtidas do exame de "padrões empíricos relativos a quase todas as democracias que existiram em qualquer lapso de tempo entre 1950 e $1990^{\prime \prime 21}$.

Mas é relevante questionar o que é considerado democracia. Porque evidentemente, há uma dimensão substantiva subjacente ao discurso científico, pretensamente universal. Em 1965, quando publicava seu primeiro ensaio sobre cultura latino-americana, Dussel ${ }^{22}$ refletia sobre o lugar da América Ibérica na história universal. Alertava então que, quando não se ultrapassa as fronteiras do cotidiano, aquilo que se conhece reivindica um sentido de originalidade e universalidade e isso tem especial relevância diante do ser histórico, cuja consciência de si mesmo é o elemento que transforma o curso do tempo em história. Por isso, alerta Dussel, a divisão da história em períodos é tão importante: é o que permite al-

20 PRZEWORSKI, CHEIBUB; LIMONGI, 2003, p. 20-24.

21 PRZEWORSKI, CHEIBUB; LIMONGI, 2003, p. 22.

22 DUSSEL, 1997, p. 11-23. 
cançar a inteligibilidade da continuidade dos fatos. O período elege o ponto de partida, e, portanto, paradigma interpretativo, que permitirá compreender os demais momentos históricos. Isso pode ocorrer mitificando a história - quando seus limites absolutizam a experiência, ou pela sua desmistificação - quando são destruídos os particularismos que impedem a compreensão da história, pois a autêntica compreensão requer que se tenham em conta outros horizontes. Para o filósofo, é necessário retroceder e ampliar os horizontes, pois não é possível explicar a história de um povo sem mostrar seu contexto, proporções e sentido, a partir da história universal e, por "história universal" o autor sugere uma integração vertical (desde o passado remoto) e horizontal (em um contexto mundial).

No caso latino-americano, a despeito da longínqua história "pré-colombiana", o "ponto de partida" para compreensão da realidade, quando muito, regressa até o fim do século XV, início do XVI. Tanto é assim, que é no nome do "descobridor" europeu que as épocas são divididas, por isso, não acidentalmente, empregou-se o termo "pré-colombiana": para demonstrar criticamente, que na modernidade ${ }^{23}$, o ponto de partida da história latino-americana passa a ser a história europeia. Atualmente, e no que se refere à democracia, a ideia de representação política se impõe como paradigma, como padrão para validação das mais variadas experiências. Por isso considera-se pertinente problematizar, a partir de uma perspectiva descolonial, certos paradigmas da modernidade, em especial os eurocentricamente concebidos, já que os referenciais de análise dos modelos latino-americanos têm

23 Situando a América Latina no contexto da história mundial, Dussel (1993) defende que o início da modernidade é o ano de 1492, pelo impacto que o encontro entre os continentes provocou na racionalidade global culminando no antropocentrismo eurocêntrico. 
sido aqueles concebidos a partir da experiência e cultura jurídica europeias.

Entretanto, nos últimos anos, alguns processos constituintes de países latino-americanos começaram a desafiar essa condição, propondo novas normatividades para organização de seus processos políticos, modelos desconhecidos ou ignorados pela tradição teórica que lhes colonizou, como a democracia comunitária, constitucionalizada na Bolívia, ou a democracia comunal, desenvolvida na ordem jurídica venezuelana. Em ambos os cenários, as práticas e conhecimentos sociais que ensejaram os novos sistemas foram - $\mathrm{e}$ em alguns casos ainda são - objeto de criminalização. Tanto pelas instituições oficiais, aplicando o direito positivo, quanto por setores sociais, mídia comercial entre outros, o que revela a insuficiência de uma epistemologia eurocêntrica para compreensão de outras ordens possíveis.

\section{Democracia comunitária na Bolívia, demo- cracia comunal na Venezuela: dois modelos em perspectivas}

Como se tem buscado demonstrar, a democracia no Ocidente observa um padrão hegemônico: o modelo de representação. Tal expressão de politicidade, concebida no contexto social que abrangeu as grandes revoluções burguesas que foram deflagradas na Europa e Estados Unidos, a partir de um processo de racionalização do poder, converteu-se em paradigma político da modernidade, reforçado com discursos prescritivos como um horizonte universal a ser perseguido pelas sociedades ditas civilizadas. Assim, democracia representativa e direito positivo, definido pelo monismo estatal, colonizaram os mais distintos processos 
políticos e culturas jurídicas no continente, levando em comum para todos os espaços conquistados e colonizados as Constituições, como cânone jurídico-político no qual ambos se assentam. Segundo Wolkmer ${ }^{24}$, desse processo emergiu uma cultura jurídica unitária no Ocidente, baseada na reprodução de idealizações normativas fruto de um tipo específico de racionalização formal e de legalidade estatal, ambas, próprias de um modo concreto de produção econômico-social. $\mathrm{O}$ autor descreve um paradigma de normatividade fundamentado no racionalismo filosófico e no iluminismo político, que favoreceu o Estado Liberal burguês-capitalista como única fonte de validade, mas também descreve a crise de hegemonia desse modelo. Tanto é assim que

Na aurora do século XXI, a América Latina viu irromper, desde o interior de sociedades devastadas pelo neoliberalismo, uma mobilização de massas que, visando superar o modelo colonizador e excludente, traçaram sua luta mirando a estrutura de seus estados nacionais e suas constituições. ${ }^{25}$

Das diversas experiências inovadoras que podem ser destacadas a partir desses processos de luta e que são reunidas no que se tem designado "novo constitucionalismo" ou simplesmente "constitucionalismo latino-americano" ${ }^{26}$, dois modelos reivindicam atenção: a democracia comunitária, prevista no artigo 11 da Constituição Política do Estado Plurinacional da Bolívia e a democracia comunal, desenvolvida a partir de bases distribuídas ao longo do texto da Constituição da República Bolivariana ${ }^{27}$ da Venezuela. Entre ambos os

24 WOLKMER, 2015, p. 69.

25 WOLKMER; ORIO, 2017, p. 35.

26 WOLKMER; MELO, 2013.

27 Chama a atenção o termo "República Bolivariana": tributário da "doutrina de Simón Bolívar, o Libertador", enunciada já no artigo primeiro da Constituição venezuelana, na verdade apoia o modelo de Estado num 
modelos há similaridades e distinções as quais ficam mais evidentes no cotejamento de seus marcos normativos. Mas, mesmo uma análise que se proponha a considerar elementos dogmáticos - constituição, legislação - não pode dar conta do tema sem a articulação de aportes interdisciplinares. Por exemplo, a democracia comunitária na Bolívia, em suas dimensões jurídica, social e ontológica, articula elementos como terra, território, autonomia e cosmovisão, numa relação indissolúvel que lhe dá sentido, um sentido que não pode ser explicado abstratamente, como se pode fazer - e de fato se faz - no campo dogmático-científico do direito positivo.

A cosmovisão abrange o reconhecimento de uma vinculação ontológica entre os povos originários e a terra, por isso, o território é tão importante: além de ser o espaço concreto onde se exerce a autonomia e os sistemas próprios de direito e política, onde se realiza a produção e reprodução da vida concreta de tais comunidades, a terra integra a própria espiritualidade de cada pessoa e comunidade. É que "a terra é a dimensão concreta do território, que por sua vez é a dimensão política sobre a qual se desenvolve a vida

pensamento paradoxal, considerada a posição dos povos latino-americanos em relação ao seu colonizador. É que, embora Bolívar de fato lutasse pela libertação latino-americana, em certos momentos não conseguia ultrapassar as fronteiras de um eurocentrismo que já apresentava traços de hegemonia. Dizia Bolívar que embora os "brancos" constituíssem uma raça menos numerosa, tinham "qualidades intelectuais que lhe [davam] uma igualdade relativa" (BOLIVAR, 1983, p. 40) e quanto ao indígena, sustentava que "O índio é amigo de todos porque as leis não estabeleceram a desigualdade entre eles e porque, para obter todas as mesmas dignidades de fortuna e de honra que concedem os governos, não há necessidade de recorrer a outros meios que o trabalho e o saber, aspirações que eles odeiam mais do que podem desejar as graças." (BOLÍVAR, 1983, p. 41-42. Sem grifo no original). De modo mais sutil, essa percepção subsiste até os dias atuais, no que as teorias descoloniais designam por colonialidade do poder, do ser e do saber (WALSH, 2012, p. 67-68). 
comunitária" 28 . Embora o território seja fundamental para a consolidação das autonomias indígenas - ou justamente por isso - a constitucionalização dos Territórios Indígenas Originário-Campesinos (TIOC) demandou dos povos e nações uma longa trajetória de luta e mobilização política ${ }^{29}$. Na constituição anterior à atual, não se reconhecia tal status, mas sim o de Terras Comunitárias de Origem (TCO), o que na prática, se prestava a negar o reconhecimento das autonomias dentro do Estado boliviano ${ }^{30}$. Como o desenvolvimento institucional que se seguiu à Constituição foi - e vem sendo - marcado por contradições e resistências conservadoras, a luta dos povos indígenas ainda persiste. Antes de prosseguir, se esclarece que, juridicamente, a democracia comunitária se efetiva a partir das Autonomias Indígenas Originário-Campesinas (AIOC), incluídas no artigo 289 da Constituição boliviana e regulamentadas por meio da Lei $n^{0} 31$ de 19 de julho de 2010, Lei Marco de Autonomias e Descentralização “Andrés Ibáñez", que estabelece os procedimentos para formação das autonomias e reconhecimento de TIOC e as disposições são estendidas também aos povos afro-bolivianos. No que

28 FERRAZZO, 2015, p. 324-325.

29 Ainda em Ferrazzo (2015), pode ser encontrado um relato sobre o conturbado processo constituinte do país, além de uma análise sobre a refundação do Estado e as novas bases constitucionais, tais como a interculturalidade, descolonização, pluralismo jurídico e a própria democracia comunitária.

30 Chumacero R. (2011, p. 16) explica que a recusa em atender às reivindicações das organizações indígenas era justificada mediante o argumento de que o reconhecimento de "Territórios" comprometeria a unidade do país, um argumento reprisado por diversos governos que se sucederam, quando na verdade, pretendiam controlar os direitos coletivos, impedindo-os de transcender as fronteiras do direito agrário. Quando se intensificam as mobilizações populares em prol da assembleia constituinte, o fortalecimento dos setores indígenas permite não somente o reconhecimento constitucional dos territórios, mas também da condição "originária" e "campesina" [acrescenta-se] com todo seu reflexo principiológico sobre o(s) sistema(s) jurídico(s) boliviano(s). 
se refere aos povos indígenas, consta na norma a existência pré-colonial, um traço reconhecido na Constituição e na lei específica das autonomias, de modo que a ancestralidade não é somente traço distintivo, mas também um dos requisitos jurídicos para a definição do Território. ${ }^{31}$

Dentre as prerrogativas das autonomias indígenas e configurando-se com um dos pontos mais desafiadores da matéria, consta a consulta prévia. A consulta prévia às comunidades ancestrais autonômicas passa a ser um procedimento obrigatório ${ }^{32}$ sempre que medidas legislativas ou administrativas lhes vierem a afetar, inclusive, quando se tratar de extração de recursos naturais, como os hidrocarbonetos. Nesse último caso, há relatos de práticas assistencialistas onde se oferecem serviços básicos - os quais deveriam ser garantidos pelo Estado - em troca da aprovação/autorização da comunidade para exploração em seus territórios, casos que em geral estão associados à execução de megaprojetos por transnacionais, assim como também há relatos de processos extrativos que são empreendidos por grandes empresas cumprir o procedimento de consulta. ${ }^{33}$ Tal cenário indica, na prática, um descompasso entre o discurso desenvolvimentista do governo de Evo Morales e a cosmovisão das comunidades indígenas ${ }^{34}$, para as quais a natureza é sagrada e não mercadoria, tampouco objeto de barganha.

Então, nota-se que a democracia comunitária tem conteúdos próprios, derivados de valores e símbolos próprios,

31 FERRAZZO, 2015, p. 325-329.

32 Conforme o artigo 30 da Constituição boliviana, que está inserido no capítulo dos "direitos das nações e povos indígenas originário-campesinos".

33 Cf. relatos e maiores reflexões sobre o tema no trabalho de Bascopé Sanjinés (2013). É interessante esse ensaio porque apresenta relatos de casos com desfechos positivos e negativos no que se refere à consulta prévia, consciência e responsabilidade ambiental e consulta prévia.

34 FERRAZZO, 2015, p. 331-334. 
explicações míticas acerca do mundo que são essencialmente formas complexas de narrativa e interpretação da realidade. Assim como não se pode pretender que tais conteúdos determinem o estilo de vida ocidental, por certo não pode pretender o inverso, tal como se dá desde a conquista através, inicialmente, do discurso evangelizador, e posteriormente, do discurso civilizador. Até porque “[...] a maneira mais direta de fundamentar a práxis de dominação colonial transoceânica [...] é mostrar que a cultura dominante outorga à mais atrasada [...] os benefícios da civilização"35. Especialmente: quando os critérios de civilização são autodeclarados e excluem o distinto, não é só plausível, mas necessário questioná-los. Então, para não incorrer na mesma "miopia eurocêntrica" ${ }^{36}$, através da prescrição de conteúdos com pretensão normativa, espera-se tão somente, sublinhar alguns aspectos procedimentais de outras tradições que podem talvez - enriquecer os processos democráticos hegemônicos no ocidente, ou senão, ao menos contribuir para uma reflexão crítica, tão necessária em tempos de acentuada crise.

Algumas das prerrogativas constitucionais das autonomias indígenas estão indicadas no artigo 289 do documento: "autogoverno como exercício da livre determinação das nações e povos indígenas originário campesinos, cuja população partilha território, cultura, história, línguas e organização ou instituições jurídicas, políticas, sociais e econômicas próprias" 37 , além da organização territorial do país, regulamentada no artigo 269, que contempla os

35 DUSSEL, 2010, p. 354.

36 DUSSEL, 1993, p. 114.

37 Sem grifo no original. Tradução livre dos autores de: "[...] autogobierno como ejercicio de la libre determinación de las naciones y los pueblos indígena originario campesinos, cuya población comparte territorio, cultura, historia, lenguas, y organización o instituciones jurídicas, políticas, sociales y económicas propias." 
TIOC. Depreende-se das reflexões de Patricia Almaraz ${ }^{38}$ que a questão é estratégica, pois a recuperação das terras originárias permite aos povos pré-coloniais reencontrar suas culturas, seus costumes e tradições; o início da reparação de quinhentos anos de injustiça e opressão. Um exemplo é a possibilidade de renúncia à propriedade privada, pois nos territórios indígenas a posse da terra é essencialmente comunitária: há a sayaña, que é o pequeno espaço para habitação e uso privativo pelas famílias, mas a relação comunal com a terra é a mais importante.

E essa questão da propriedade privada remete a outra crucial, que é a questão do individualismo. Como os sistemas modernos ocidentais (em especial a política e o direito) se desenvolvem em função do indivíduo, a sua implementação na América Latina não consegue contemplar as comunidades pré-coloniais, cujos integrantes, em razão de suas racionalidades ou cosmovisões, não podem se conceber isoladamente, pois só encontram o sentido de sua própria existência no contexto da comunidade. Sobre o povo boliviano, Álvaro García Linera ${ }^{39}$ explica que as entidades coletivas existentes no país - que vão desde os ayllus ${ }^{40}$ até as associações de trabalhadores - são mais expressivas que qualquer manifestação individualista e é por meio desses grandes e diversos coletivos que exercem o controle social, reivindicam direitos, indicam representantes, enfim, atuam em todos os campos

38 ALMARAZ, 2005, p. 2; 5 .

39 LINERA, 2006, p. 78.

40 Os ayllus são uma forma de organização coletiva transmitida entre sucessivas gerações desde os tempos do Império Inca, onde tiveram início. Constituíam-se em pequenas comunidades agropastoris, que podiam abranger de um pequeno número até centenas de famílias. Baseavam-se no trabalho cooperativo, sem divisão social em classes e sem propriedade privada (CÁRCERES, 17; 27; JESUS OSCAR, 2000, p. 69). Se a "célula" da sociedade ocidental moderna é a família, a célula de muitas das sociedades pré-coloniais era o ayllu. 
da vida pública boliviana. Ou, nas palavras do autor - talvez subvertendo categorias eurocêntricas: é como formam "uma moral cívica de responsabilidade cidadã".

A democracia comunitária se articula com outro princípio inserido na ordem constitucional boliviana em 2009, já no primeiro artigo: o pluralismo jurídico, que garante às autonomias indígenas o respeito aos seus sistemas ancestrais de direito. E, de fato, não seria possível a efetivação plena de um, sem o desenvolvimento do outro. Quer dizer, não seria possível falar em autonomia e desenvolvimento de processos políticos próprios, sem o desenvolvimento simultâneo de sistemas normativos próprios. E além disso, ambos sempre estiveram no cotidiano latino-americano, inclusive no Brasil, como constatado por Antonio Carlos Wolkmer ${ }^{41}$ na tese de doutoramento que apresentou uma outra perspectiva em relação ao pluralismo jurídico. Assim, uma vez assegurado o autogoverno, os processos democráticos e sistemas normativos próprios de cada ancestralidade ampliam as condições de respeito ao complexo mosaico jurídico-político que compõe as sociedades latino-americanas, e a boliviana em específico. Importante destacar ainda que os povos e nações indígenas não atuam somente no âmbito de seus territórios, mas interagem uns com os outros e reivindicam participação nas instituições oficiais, demandando o desenvolvimento de novos procedimentos pelo Estado. Para Leonel Júnior ${ }^{42}$ estão surgindo novas instituições democráticas na Bolívia, que o autor conceitua como uma espécie de "democracia intercultural". ${ }^{43}$

41 WOLKMER, 2015.

42 LEONEL JÚNIOR, 2014, p. 284-287.

43 A "democracia intercultural", conceito com crescente popularidade, não deve ser confundida com uma "quarta" forma de democracia, para além das democracias representativa, participativa e comunitária, mas sim, 
A ideia de democracia intercultural permeia as formas habituais de ação coletiva, como a comunitária, as assembleias sindicais ou urbanas, e por isso não pode ser compreendida como conceito vazio ou abstrato: se revela pela mobilização popular no espaço político, afetando o poder constituído. A democracia intercultural não é um "encontro de iguais", pois se expressa na interação entre sujeitos e realidades distintas, cujas relações são sempre dinâmicas, podendo ser modificadas conforme a presença e pressão dos grupos ${ }^{44}$.

O advogado aimará Moisés Idón Chivi Vargas ${ }^{45}$ assinala que surge na Bolívia um direito, a partir de vertentes "clandestinas, mas fortemente reais", a resistência indígena, que orienta o programa da nova constituição, sem se referenciar no "conhecimento jurídico tradicional". Segundo o autor, a ruptura que o Estado Plurinacional representa pode viabilizar a construção de uma democracia mais igualitária. Para usar a categoria de Dussel, há novos "projetos" orientando a constituição, mas agora, os projetos são determinados pelo cotidiano de povos latino-americanos, principalmente os historicamente subalternizados. Mas, assim como na Venezuela, onde a democracia comunal é uma experiência envolta em controvérsias, a democracia comunitária boliviana e sua integração intercultural com os demais espaços do Estado Plurinacional enfrentam contradições e, ainda mais, objeções. Ambos os paradigmas, pluralismo

como um método de integração e harmonização entre os distintos espaços e processos políticos existentes no país. Sobre a popularização do conceito, muito se deve à edição da lei do regime eleitoral na Bolívia, em 30 de junho de 2010, que, já no primeiro artigo anuncia que o regime eleitoral é regulamentado para o "exercício da democracia intercultural", baseada na complementariedade entre as três formas constitucionalmente previstas.

ZEGADA C., 2017, p. 572-574.

CHIVI VARGAS, 2009. 
jurídico e democracia comunitária, enfrentam uma tensão recolonizadora que, por um lado ambiciona enclausurar os sistemas não estatais no interior de suas comunidades e, quando não possível, investe para subsumir os modelos tradicionais nas institucionalidades estatais. Esse processo de subsunção nem sempre é dialético ${ }^{46}$, já que, na maioria das vezes, os sistemas comunitários são reconvertidos para a institucionalidade oficial estatal.

Em análise mais crítica, Vargas Delgado ${ }^{47}$ lamentava o desenvolvimento do sistema de democracia comunitária boliviano, já que os procedimentos tradicionais eram observados somente na designação dos representantes, que uma vez nomeados, passavam a compor o sistema representativo, consolidando-o, enfim. E o próprio Sistema Intercultural de Fortalecimiento Democrático (SIFDE), que é diretamente vinculado ao Tribunal Supremo Eleitoral, vem submetendo a democracia comunitária a uma homogeneização de procedimentos, aproximando-os cada vez mais do sistema representativo, enquanto se afasta dos processos comunais. Essa dinâmica já havia sido percebida por Boaventura de Sousa Santos $^{48}$ como uma grande "armadilha" da modernidade que incessantemente converte as energias emancipatórias em regulatórias. De qualquer modo, tal relato denota desafios e contradições externas ao modelo comunitário, as quais podem ser consideradas como processos de recolonização

46 Num primeiro momento pode soar como paradoxal esperar dialeticidade na subsunção, mas Dussel (2012, p. 222), num dos momentos do desenvolvimento de sua Ética da Libertação, quando revisa a teoria de Jonh Rawls assumindo-a como mediação para analisar criticamente paradigmas do "centro", explica que sua arquitetônica se baseia numa relação de codeterminação entre princípios e, quando ocorre subsunção, isto se dá sem negação por um quanto aos demais. Com esse avanço metodológico, abrem-se possibilidades de diálogo intercultural entre distintos horizontes.

47 DELGADO, 2014.

48 SANTOS, 1997, p. 93. 
dos sistemas, mas também existem contradições internas, inclusive identificando no modelo representativo certos "mínimos" invioláveis.

Nesse sentido, a maioria dos estudos sobre os sistemas andinos de direito e política apontam para a existência não de um, mas de vários sistemas distintos: de várias justiças, de várias democracias. A eventual identificação de similaridades - como a soberania da assembleia, a recomposição da harmonia comunitária como horizonte, entre outros significa que todas as tradições sejam baseadas nos mesmos valores. Então, diante da preocupação com o risco de violação de direitos políticos, as próprias organizações indígenas reconheceram que determinadas conquistas democráticas, como a igualdade e universalidade do voto, não poderiam sofrer retrocesso, de modo que o artigo 26 da Constituição boliviana prevê a supervisão pelo Órgão Eleitoral sempre que tais garantias não estiverem contempladas nas práticas da democracia comunitária.

Um derradeiro aspecto a se considerar, por hora, diz respeito à colonialidade do saber, que nega as "epistemologias do Sul", ou seja, as teorias e modelos concebidos fora do eixo euro-norte-americano, que opera, conforme Catherine Walsh ${ }^{49}$, assumindo o eurocentrismo como ordem exclusiva da razão, excluindo e desqualificando os saberes que não nascem do homem branco europeu ou europeizado. Por isso o sociólogo e líder aymará, Félix Patzi ${ }^{5051}$, sustenta que um dos pressupostos da descolonização implica em se admitir que as civilizações indígenas têm institucionalidades que são

49 WALSH, 2012, p. 67.

50 PATZI, 2013, p. 18.

51 Félix Patzi, recentemente, começou a incursionar pela institucionalidade estatal boliviana, assumindo no ano de 2015 a função de Governador de La Paz. Cf. em < http://www.gobernacionlapaz.gob.bo/gobernador/ >. 
possíveis de implementar também em contextos nacionais e sociedades e organizações não indígenas. Outro ponto fundamental está no reconhecimento de que a recuperação de instituições originárias precisa ultrapassar o confinamento, tal recuperação impõe o desenvolvimento dos respectivos processos, contando inclusive com o aporte das tecnologias contemporâneas, já que a descolonização não parte da negação absoluta dos acúmulos da sociedade ocidental.

Essa foi, em largos traços, uma tentativa de caracterização da democracia comunitária, a partir de alguns de seus méritos, desafios e contradições. Adiante, após a repetição desse processo no contexto da democracia comunal venezuelana, alguns pontos serão retomados enquanto mediações para avançar na tentativa de uma reflexão descolonial sobre a relação entre democracia e cultura. Antes, vejam-se alguns aspectos relativos à experiencia venezuelana.

A Constituição bolivariana da Venezuela contempla em diversos momentos a soberania popular, num nítido esforço por deslocar o conceito do campo da abstração e assegurar as bases para sua efetivação material. Um exemplo é a previsão incluída no artigo 70, de que as decisões tomadas nas assembleias de cidadãs e cidadãos ${ }^{52}$ têm caráter vinculante. No mesmo artigo, dispõe que quaisquer formas associativas de produção, orientadas pela cooperação, solidariedade e autogestão, são incluídas entre as formas de protagonismo popular. A esse segue-se a determinação, no artigo 158, de descentralização política, para aproximá-la do povo, assim como a criação de entidades locais nos municípios - designadas por "paróquias" - atendendo à iniciativa comunitária

52 Diferentemente da constituição brasileira, a venezuelana, em todo seu texto, adota flexão de gênero. Reconhecendo a subsistência da dominação patriarcal, essa opção da constituinte transcende o campo do simbólico e emerge como opção política fundamental na nova ordem. 
ou vicinal, prescrita no artigo 173. Mas, o dispositivo que se revelaria mais controverso no desenvolvimento da nova ordem constitucional é o que trata dos Conselhos Locais de Planificação Pública ${ }^{53}$ (CLPP), que nos termos do artigo 182 devem ser presididos pelo prefeito ou prefeita (alcalde), e integrado por conselheiros, presidentes das juntas paroquiais e representações das organizações vicinais entre outros. Antes de esboçar alguns aspectos dessa controvérsia, é importante perceber que

As sucessivas referências à organização de base, local e territorial, para além do rompimento com um sistema político exclusivamente representativo, eram ademais expressões das experiências organizativas já esboçadas nos barrios venezuelanos (as assembleias de bairros remontam à década de 1980) e, ademais, na cultura ancestral dos povos tradicionais (elementos que aparecerão depois nas formulações do próprio Chávez $)^{54}$.

Das organizações de base decorrem as chamadas "comunas". Segundo Darío Azzellini, a democracia venezuelana conta com uma forma democrática não representativa, estruturada com base nos Conselhos Comunais, os mais importantes instrumentos de participação e de construção do poder popular. Tais Conselhos, que congregam dezenas de famílias, têm nas Comunas o mais alto nível de coordenação, sendo modelos de autogestão e de controle operário. Mas alerta que os Conselhos oscilam entre espaços autônomos e plurais e a influência estatal. Em todo caso, é na trajetória histórica das Comunas - e não do Estado - que Azzellini identifica a intersecção entre a luta popular por uma democracia participativa - e também pelo socialismo ${ }^{55}$.

53 Os Consejos Locales de Planificación Pública foram regulamentado através da lei n. 37463, de 12 de junho de 2002.

54 WOKMER; ORIO, 2017, p. 43. Grifo no original.

55 AZZELLINI, 2012, p. 117-121. 
Igual percepção se encontra em Wolkmer e Orio, que descrevem a estrutura democrática das comunas como parte de um movimento bolivariano, cujo horizonte era a construção de um socialismo do século XXI, e nesse contexto, redefiniu-se a ideia de participação popular a partir do autogoverno de base. Tal percepção foi incluída na constituição venezuelana de 1999, traçando as diretrizes do programa de governo com o qual se pretendia catalisar o poder popular. No marco normativo, explicam os autores, esse projeto teve início em 2005, com a lei das comunas, onde surge o Conselho Comunal, subordinado ao poder público municipal. Essa situação mudou em 2006, quando o novo marco normativo desvencilhou os conselhos dessa subordinação, vinculando-os diretamente à Presidência da República. Todavia, o intento de avançar no fortalecimento desses conselhos, por meio de reforma constitucional, restou frustrado pela derrota no referendo realizado em 2007. A retomada do projeto ocorre em 2009, quando é editada lei que regulamenta os conselhos comunais, cujo escopo é permitir ao povo o exercício do governo comunitário, conforme indica o artigo segundo da norma. E "esta reconfiguração dos Conselhos Comunais traduziu a primeira regulação de uma instância do poder popular a partir da orientação decididamente socialista da revolução bolivariana" 56 .

Mais um elemento chama atenção dentre os que os autores trazem ao debate: diz respeito aos precedentes que conduziram ao modelo democrático comunal, localizados em um dos pronunciamentos de Hugo Chávez, do qual se reproduzem fragmentos significativos:

Quando falamos dos antecedentes das comunas, temos nossos povos indígenas, em especial nos Andes venezuelanos e nos Andes colombianos [...] Aqui nossos aborígenes, há milhares de

56 WOKMER; ORIO, 2017, p. 45-46. 
anos viviam em comunas, eram os comuneiros dos Andes, muito arraigados à terra [...] Também no Paraguai, os comunheiros do Paraguai antes da chegada dos conquistadores [...] Na América Central os Maias viviam em comunas; na América do Sul os Incas chegaram a formar um império que partiu dos Andes venezuelanos e se estendeu por todo o Cone Sul: o Império Inca ${ }^{57}$. Tradução livre dos autores $\left.{ }^{58}\right)$.

De fato, as insurgências populares deflagradas nas últimas décadas revelam a história mais longínqua do continente, encoberta e ocultada pelo colonizador, mas que ressurge clara e repleta de significados, e, tanto na Venezuela, quanto na Bolívia - e em outros países relacionados ao "novo" constitucionalismo, notadamente o Equador - recompõem a memória das tradições ancestrais e ensinam as lições do passado, que, imbricando-se com elementos da contemporaneidade, reinventam as instituições, inauguram novas possibilidades para a vida pública; são a condição de possibilidade para uma "refundação do Estado". Então, apesar de todas as objeções e controvérsias que a experiência comunal venezuelana representa, sua fundamentação expande os cânones coloniais, que, conforme Dussel ${ }^{59}$, limitavam-se ao século XVI e o que dele se pudesse apreender nos estreitos limites do eurocentrismo.

Mayra Goulart da Silva, cuja tese doutoral se ocupou da questão da democracia na Venezuela, publicou pouco tempo

57 CHÁVEZ, 2009, p. 5.

58 Cuando hablamos de los antecedentes de las comunas, tenemos a nuestros pueblos indígenas, sobre todo en los Andes venezolanos y en los Andes colombianos [...] Aquí nuestros aborígenes, hace miles de años, vivían en comunas, eran los comuneros de los Andes, muy arraigados a la tierra [...] También en el Paraguay, los comuneros del Paraguay antes de la llegada de los conquistadores [...] En Centroamérica vivían en comuna los mayas; en Suramérica los incas llegaron a formar un imperio que rozó los Andes venezolanos, y se extendió hasta el cono Sur: el Imperio inca

DUSSEL, 1997. 
depois, análise que parece oscilar entre celebração e preocupação, o que na verdade é bastante compreensível, dada a complexidade do cenário político. Veja-se: no ano de 2015, quando seu artigo foi publicado, a pesquisadora deu conta da existência de cerca de quarenta mil conselhos comunais na Venezuela, com uma impressionante amplitude de competências, uma "grandiosidade" que a levou a qualificá-los como a organização social mais importante da Venezuela e talvez até do continente e, ainda assim, todo esse potencial se via em risco pela polarização política e pela ingerência do governo. Mas, apesar das contradições no processo democrático, os conselhos comunais viabilizavam a superação do passado centralista que o país experimentou. Isto porque, sem reconhecer na constituição venezuelana de 1999 "feições revolucionárias", reputa à norma algumas inovações, em especial no campo democrático, marcado pelo o caráter participativo. Com um "detalhe": na constituição anterior, tal caráter não adjetivou a democracia em nenhum momento. Entre uma constituição e outra a autora identifica a transição entre o modelo "puntofijista", dos partidos e corporações, para efetivação da democracia, o "projeto chavista" devotado ao protagonismo popular, por meio da participação cidadão direta. Este projeto em choque com o hiperpresidencialismo: um elemento de continuidade na ordem ${ }^{60}$.

Valdenésio Aduci Mendes ${ }^{61}$, que também investigou a democracia na Venezuela, com delimitação específica nos Conselhos Comunais, por ocasião de sua tese de doutorado, realizou estudo junto a cento e vinte conselhos comunais, entre os anos de 2009 e 2010. Em decorrência, concluiu que o sistema comunal padecia de perda de autonomia, mitigação do pluralismo político e recentralização do poder na figura

60 SILVA, 2015.

61 MENDES, 2013. 
presidencial, o qual vinha verticalizando as relações através dos recursos que distribuía diretamente - e privilegiando grupos leais ao seu projeto político: o pesquisador verificou, entre participantes de conselhos comunais, noventa por cento de filiações partidárias e, dentre os filiados, oitenta e seis por cento integrando o Partido Socialista Unido da Venezuela (PSUV), mesmo partido do então presidente Hugo Chávez.

Se ambos os pesquisadores concordam no diagnóstico de um hiperpresidencialismo na Venezuela, os dados selecionados e respectivas análises culminam em conclusões distintas. Considerando que os estudos foram realizados no mesmo período, isso dá uma ideia da complexidade da realidade política no país.

Os dados analisados por Silva são mais abrangentes, mas, ao contrário de Mendes, não foram coletados in loco. Esses dados são extraídos de um estudo realizado em 200962, que abrangeu 1138 Conselhos Comunais e cujas entrevistas demonstraram que são expressivas as percepções da comunidade de que: a) a iniciativa de formação dos conselhos é da própria comunidade $(85 \%)$, b) a população se envolve nas discussões políticas $(84 \%)$; c) há espaço para divergências políticas $(80 \%)$ d) não ocorrem conflitos nos processos decisórios (55\%), e) dos que sustentam a existência de conflitos, 79\% reconhecem sua resolução pelo diálogo e f) não houveram relatos de intervenção excessiva do Estado ${ }^{63}$. Por

62 Por instituição mantida pelo Estado Venezuelano, a Fundação Gumilla, conforme explica a autora.

63 Por outro lado, a própria autora traz pesquisa realizada em 2011 onde 42,6\% da população relata ter medo de falar sobre política com a vizinhança, um claro indicativo da polarização política no país. Mas a mesma pesquisa indica que, sobre a questão da ingerência do governo nos conselhos, $27 \%$ acreditam na autonomia da comunidade, enquanto $25,9 \%$ acreditam que o poder é exercido pelo Estado, além de 36\% considerarem os conselhos o melhor caminho para resolução dos problemas da comunidade, no que desacordam 23,3\% dos entrevistados. A questão mais interessante é, 
isso conclui que, apesar das críticas ao modelo comunal, há grande satisfação entre os atores que participam desse espaço democrático ${ }^{64}$.

No que se refere à percepção de que os conselhos comunais asseguram espaço para divergência política, Mendes chega à conclusão contrária através de sua pesquisa:

A participação em muitas reuniões de CCs nos permitiu observar a forte presença de pessoas filiadas ao PSUV, portando camisetas, chapéus e outras marcas do partido, sinalizando com essas indumentárias, uma mostra de força e de disputa de terreno, restringindo a presença de outras correntes partidárias ${ }^{65}$.

O que se percebe é que as bases normativas são profícuas, do ponto de vista de uma radicalização nos processos democráticos, mas seus desdobramentos na prática nem sempre realizam o potencial da democracia comunal. Também fica a dúvida se o tema alcançou dentre o povo venezuelano o amadurecimento necessário para se sustentar diante da resistência da oposição e das forças conservadoras, que não desejam ver a concretização da soberania popular. Essa tensão ficou evidente com a constituinte de 2017, um processo conturbado, já com centenas de mortos - assim como foi o boliviano entre 2007 e 2008 - em que a Procuradora-Geral, Luisa Ortega foi destituída e proibida de sair do país, após denunciar uma "ruptura constitucional", manipulação de votos entre outros pontos ${ }^{66}$. Por outro lado, jornalistas que acompanharam a votação da constituinte, como o correspon-

todavia, relativa ao reconhecimento da possibilidade de exercer influência sobre o governo: $42,4 \%$ dos entrevistados acreditavam poder fazê-lo (SILVA, 2015, p. 21).

64 SILVA, 2015, 16-17.

65 MENDES, 2013, p. 21.

66 SCHARFENBERG, 2017. 
dente do Brasil de Fato, Leonardo Fernandes ${ }^{67}$, sustentam que a mídia internacional, para construir uma matriz de opinião que deslegitime o processo, ao mesmo tempo que motiva a oposição a resistir, tem "criado uma Venezuela", generalizando conflitos pontuais e cenários específicos, como um ataque a bomba deflagrado por grupos de oposição ao governo contra a guarda nacional, ou a imagem gerada pela oposição de uma votação esvaziada, ignorando longas filas geradas em outros centros. O correspondente explica o esvaziamento: muitos eleitores "não puderam votar em suas respectivas seções eleitorais, impedidos pelos grupos violentos da oposição".

Pensando nos precedentes bolivianos, acredita-se que o processo constituinte atual da Venezuela (que é mais uma aposta do governo para dar seguimento ao seu programa político), em que pese seus méritos, tem um desafio maior que os colocados pela oposição nacional: avançar de projeto do governo, consolidando-se como verdadeiro projeto do povo.

\section{Insurgência epistemológica e cultura jurídica latino-americana}

O ano de 2016 foi bastante conturbado no cenário político latino-americano, especialmente no Brasil ${ }^{68}$ e na Venezuela. Em comum, os países têm controvérsias político-jurídicas que dividem a opinião pública e de especialistas, sugerindo

67 FERNANDES, 2017.

68 A crise de representatividade do governo pode ser demonstrada na série histórica traçada com dados do Latinobarômetro, no período de 2002 a 2016, os índices mais elevados de aprovação foram os de 2010, com 86\%, caindo para 22\% em 2016. Mas em julho de 2017 os índices caíram ainda mais: 7\%. Conferir em: <http://datafolha.folha.uol.com. br/opiniaopublica/2017/06/1896143-somente-7-aprovam-governo-temer. shtml>. 
graves crises institucionais. Distinguindo-os, os modelos de democracia, pois como visto, o modelo venezuelano regulamentou novas institucionalidades, enquanto que o Brasil segue apostando no sistema hegemônico de representação. Em setembro de 2016 o Latinobarômetro ${ }^{69}$, publicou seu relatório anual, no qual chamou atenção o quesito formulado para mensurar o apoio à democracia em diferentes países do continente. Apesar das duras críticas formuladas pela sociedade e instituições estrangeiras, os mais promissores índices foram verificados na Venezuela, em que $77 \%$ da população considerava o sistema vigente como o melhor modelo, em quinto lugar a Bolívia com $64 \%$ e em penúltimo lugar entre os dezenove países indicados, o Brasil, com $32 \%$ de apoio. No caso do Brasil, uma queda brusca (vinte e dois pontos) foi destacada na avaliação do relatório. Reforçando a percepção de uma crise política, quando o quesito abordou o comprometimento do governo com o povo, o Brasil ficou na última posição, com os mais baixos índices.

Na relação entre democracia e economia - lembrando que para Przeworski, Cheibub e Limongi não é a cultura, mas sim a economia que define a estabilidade democrática de um país -, de fato, Brasil e Venezuela apresentam os perfis de maior frustração com as instituições políticas e os mais altos índices de insatisfação com a economia. Na Bolívia os indicativos se invertem: é um dos países mais satisfeitos nos dois quesitos. Mas isso basta para afirmar que a democracia não depende da cultura, mas sim dos fatores econômicos? Talvez, se fosse possível identificar um conceito genuina-

69 Entidade sem fins lucrativos, sediada no Chile que pesquisa dados a respeito do desenvolvimento da democracia, economia e sociedade no continente latino-americano. Os dados são coletados através de entrevistas (cerca de vinte mil por ano), realizadas em dezoito países do continente e convertidos em indicadores de opinião pública. A página pode ser acessada em: < http://www.latinobarometro.org >. 
mente universal de democracia. Mas o argumento central dessas reflexões é a "democracia" ilustrada naquele e noutros trabalhos, é um modelo axiomático: o particular assumido como universal. Tanto que os indicadores sistematizados pelo Latinobarômetro, e que também aportaram a análise sobre democracia e cultura ${ }^{70}$ mencionada na primeira seção, são obtidos por meio de quesitos que orbitam precipuamente em torno do modelo representativo ${ }^{71}$. Mas as experiências discutidas na segunda seção transcendem esse modelo e reivindicam o reconhecimento de novas institucionalidades possíveis, pois "Fazer e praticar democracia nos nossos países é descolonizar as estruturas fundamentais do Estado republicano, monocultural e monolinguístico"72 (Tradução livre dos autores ${ }^{73}$ ).

Por isso, consideram-se as abordagens descoloniais um caminho possível para a insurgência epistemológica diante da racionalidade moderna eurocêntrica. Trata-se da urgência de uma "racionalidade critica libertadora descolonial" reconhecendo que a "práxis comunitária é decisiva", como sustenta Celso Ludwig ${ }^{74}$, cujas reflexões levam ainda à percepção de

$70 \quad$ PRZEWORSKI et. al, 2003.

71 Um exemplo: no bloco temático "la democracia $>>$ la cultura cívica e política >> participación política" um dos quesitos é "com que frequência trabalha para um partido ou candidato?" e os demais quesitos, basicamente, são referentes à pré-disposição popular em participar de marchas e protestos. Conferir em: < http://www. latinobarometro.org/latOnline.jsp >. Ora, tais quesitos sugerem a participação como não mais que meio para influenciar as esferas representativas e não como fim em si, possibilidade de exercício do poder político.

72 VEGA CAMACHO, 2010, p. 90.

73 "Hacer y practicar democracia en nuestros países es descolonizar las estructuras fundamentales del Estado republicano, monocultural y monolinguístico."

74 LUDWIG, 2015, p. 125. 
que a exterioridade periférica (latino-americana) não pode ser compreendida dentro dos limites dessa racionalidade e sua "insuficiência epistêmica"75. A sua proposta vem na forma de um "giro des-colonial", que constitui uma reflexão filosófica distinta da hegemônica tendo na filosofia da libertação uma de suas manifestações possíveis. A partir da lógica da totalidade $^{76}$, nega-se a diversidade periférica, pela subsunção à mesmidade/unidade. Como já colocado, os paradigmas extraídos da tradição particular europeia e convertidos em modelos universalmente válidos. Por isso a defesa de

[...] um pluralismo filosófico como alternativa para as alternativas, como alternativa para a alteridade ou para as alteridades. E nessa condição, ver o sentido da construção e da produção do pluralismo filosófico e seu sentido para o pluralismo jurídico, na ótica do já anunciado giro descolonial ${ }^{77}$.

O jurista argentino Alejandro Médici, já influenciado por essa inversão epistemológica, reconhece nas experiências de democratização vividas no Sul, a institucionalização da demodiversidade, a expansão do "cânone democrático proposto pela teoria hegemônica norte-atlântica [em suma], constituem uma fonte de renovação para a teoria democrática"78. Exeni Rodrigues ${ }^{79}$ associa o reconhecimento constitucional do "princípio de demodiversidade" à primeira eleição de um presidente indígena, num país majoritariamente indígena, o que ocorreu apenas no início do século

75 LUDWIG, 2006, p. 194.

76 Totalidade é uma categoria empregada por Dussel para designar os modelos hegemônicos na modernidade e que consolidaram o eurocentrismo enquanto base da correspondente racionalidade. Essa categoria é fundamental nas ideias e reflexões que o jusfilósofo vem acrescentando à teoria jurídica ao longo das últimas décadas.

77 LUDWIG, 2015, p. 117. Grifo no original.

78 MÉDICI, 2012, p. 83-84.

79 EXENI RODRIGUES, 2017, p. 600-601. 
XXI. E a dimensão substantiva desse princípio se configura na coexistência conflituosa ou pacífica de distintos modelos democráticos, assumindo que não existe um "modelo universal", desafiando o modelo hegemônico que desqualifica, descarta ou torna invisível as experiências existentes. Mas a riqueza dessas experiências não pode ser desperdiçada. Tampouco, se trata de negar a democracia representativa, mas sim permitir que, a partir dos sucessos e fracassos pedagógicos de ambas, se extraiam novas possibilidades. É uma perspectiva que já orienta a teoria crítica no continente há tempos e se renova e fortalece no cenário atual:

Quando se pensa em novo paradigma de se fazer política, não se está abandonando, ou excluindo, inteiramente a democracia representativa burguesa e suas limitadas e insuficientes regras institucionais formais (como partidos políticos, proporcionalidade, votos etc.), mas sim desenvolvendo formas de democracia de base (participação, gestão compartida e sistema de conselhos) capazes de conviver com certos institutos positivos da democracia por delegação. A convergência deve levar em conta, sobretudo, a participação, o controle e a representação vinculante dos interesses de todos os setores da sociedade, seja sob a experiência de sujeitos individuais, seja sob a expressão de sujeitos coletivos ${ }^{80}$.

As perspectivas descoloniais, por se pautarem no compromisso com o povo, pela valorização da práxis, enquanto ação transformadora conjugada com consciência reflexivo-teórica, e, assumindo como mediação reflexiva ${ }^{81}$ as mais variadas experiências democráticas, podem ser prelúdio de novos caminhos, e nao só para a política. As matrizes descoloniais latino-americanas tem inspirado um "pluralismo liberador", conforme explica Wolkmer ${ }^{82}$, com base

80 WOLKMER, 2015, p. 300.

81 Proposta metodológica de Enrique Dussel desenvolvida em sua Ética da Libertação (2012).

82 WOLKMER, 2015, p. 81-82. 
democratico-participativa e que rejeita as propostas engendradas nos países "ricos do centro", do Norte global, voltadas às necessidades do mercado, do capitalismo monopolista globalizado. Nesse tipo de juridicidade pluralista proposta por Wolkmer, o espaço público privilegia a participação das sociabilidades excluidas, porque as reconhece capazes de instaurar, a partir de seus processos históricos e lutas, novos direitos, legitimados pela vontade e manifestação autêntica da comunidades.

Para Diego Cárdenas ${ }^{83}$ a cultura jurídica latino-americana é híbrida, compondo-se de instituições e modelos trazidos da Europa e sua adequação às realidades e instituições no continente, numa interação que o autor define como de "intercâmbio". Como consequência desse intercâmbio, identifica paradigmas predominantes na cultura jurídica e próprios dessa cultura, tendo na independência das colônias o primeiro passo, entretanto, apenas reestruturando-se e não rompendo significativamente a relação com a Europa, inclusive porque as ideias emancipatórias que ressoaram entre a elite de criollos brancos no continente foram as concebidas nas revoluções burguesas, vinculadas ao ideário econômico capitalista. Emerge desse processo o Estado-nação, e como paradigmas da cultura jurídica local o pluralismo, a ineficácia e o autoritarismo. O modelo constitucional é idealizado pelas elites, por isso, a caracterização do pensamento jurídico no século XIX pautou-se no transplante e manutenção da racionalidade europeia. Mas na passagem do século XX para o XXI despontou uma visão contra-hegemônica em que as classes populares se impõem contra os interesses elitistas e resistem tanto no campo da política, quanto no campo do direito. A coexistência de instituições eurocêntricas com as emergentes a partir das lutas populares tem ensejado a perceção de

83 CÁRDENAS, 2016, p. 62-71; 79. 
duas Américas: uma europeia, que segue reproduzindo os modelos colonizadores, e uma insurgente, emancipatória e contra-hegemônica, por isso Cárdenas conclui que atualmente a cultura jurídica latino-americana é um espaço inacabado e disperso, diante do que os estudos jurídicos críticos começam a assumir posição de suma importância, mesmo sem ainda produzir o mesmo impacto que as teorias europeias presentes no continente. E conclui o autor pela necessidade de superação dos paradigmas latino-americanos - ineficácia, autoritarismo, pluralismo - para aprofundar a verdadeira independência no continente.

Naturalmente, Cárdenas e Wolkmer não se referem ao mesmo tipo de pluralismo. É necessário esclarecer, pois uma crítica generalizada reconduziria ao monismo jurídico, o qual, estatal ou provindo de outra fonte, atua como força colonizadora sobre a diversidade latino-americana. Há diversos tipos de pluralismo, conforme indica Wolkmer ${ }^{84}$, um deles, o pluralismo jurídico do capitalismo globalizado de acumulação flexível. O desafio das sociedades periféricas consiste em superar esse tipo de pluralismo.

O desenvolvimento da cultura jurídica ocidental, aproximando, até a quase completa identificação formal, poder político e direito, submeteu também ambas as esferas à influência do mercado, do liberalismo econômico, de modo que, sendo a economia determinada pela lógica capitalista, as análises economicistas da democracia privilegiarão esse tipo de sociedade. Nesse sentido, contundente a crítica de Boron $^{85}$ a respeito da confusão que se faz atualmente, conferindo o caráter de democrático a partir do critério econômico (capitalista) e ignorando os elementos essenciais de uma democracia, tais como o governo da maioria em favor dos

84 WOLKMER, 2015, p. 228-229.

85 BORON, 2009. 
pobres. Na América Latina, esse desafio implica em descolonizar as estruturas jurídicas junto às políticas, reconhecer a validade epistemológica de outros modelos. Ao homem abstrato, indivíduo universal modelo da modernidade, opor a humanidade concreta que compõe as realidades periféricas. Trata-se de reconhecer, conforme propõe a filosofia da libertação, o ser humano concreto, que enfrenta a violação sistemática de seus direitos e as lutas desse sujeito têm na relação entre o direito alternativo ${ }^{86}$ e a filosofia da libertação (o primeiro como instrumento, a segunda como fundamentação) um espaço estratégico de resistência ${ }^{87}$.

O caso citado da democracia comunitária mostra como os povos indígenas bolivianos associaram as pautas jurídica e política, buscando assegurar suas autonomias conforme as regras de sistema de direito vigente, ou seja, desde o texto constitucional, mas redefinindo-o de modo a ampliar suas fontes, constitucionalizando também o pluralismo jurídico. Como resultado, a possibilidade de refundação do Estado, num processo inacabado que sobreleva a importância do desenvolvimento de epistemologias que permitam descolonizar os conceitos de cultura, democracia e assim, reconhecer novas institucionalidades e juridicidades insurgentes.

\section{Conclusão}

Há um desafio inicial posto para as abordagens descoloniais: superar o fetichismo da racionalidade-moderna-hegemônica, expresso na quase sacralização da "neutralidade"

86 O direito alternativo é um dos exemplos que ilustra como na América Latina corre simultaneamente às instituições hegemônicas, desenvolvimentos próprios do continente de tal institucionalidade. Fala-se em "cultura juridicista" do povo latino-americano, inclusive dos povos indígenas, conforme relata o jurista mexicano Jesus Antonio de la Torre Rangel (2010).

87 TORRE RANGEL, 2001, p. 178; 188-190. 
científica e na pretensão de universalidade de seus projetos. Inegável que o lugar que cada pessoa ocupa no tempo e no espaço é componente indissociável da própria racionalidade, mas a diferença entre ser condicionado ou apenas influenciado pelo entorno decorre da postura que se assume perante o mesmo. Na tradição cartesiana, cultura e ciência são tratadas como antíteses uma da outra, e não como dimensões que se determinam reciprocamente. $\mathrm{O}$ desafio descolonial consiste em reconhecer o "lugar da fala" e a carga de parcialidade que inevitavelmente o acompanha, assim como, admitindo novos saberes sem a pretensão de universalidade, sem a dogmatização de conceitos e, portanto, enriquecidos pelo pluralismo, em contraposição aos monismos modernos.

A democracia na América Latina, historicamente, sentiu as contradições e desajustes entre os modelos do centro e as necessidades periféricas. A dominação neocolonial e a ingerência de interesses do capitalismo global só fizeram agravar as crises. De modo não exatamente simultâneo e tampouco com a mesma forma e intensidade, as mobilizações populares ocorridas nas últimas décadas, mais que processos de transformação política, significaram o questionamento e problematização diante dos paradigmas hegemônicos. Particularmente, significou a negação de que a cultura jurídica latino-americana seria incompatível, ou imatura para desenvolver modelos civilizatórios próprios. Tal negação vem se dando pelas práxis de luta e pela ocupação de espaços teóricos. No caso das novas formas democráticas de orientação comunitária, essas pautam-se em concepções políticas desenvolvidas com base numa "epistemologia indígena". Compreender esse processo envolve reconhecer quais são os desafios colocados pelas tendências recolonizadoras e quais são os desafios próprios dos modelos enquanto processos em desenvolvimento e, portanto, sujeitos a desacertos. 
Dito isso, se reconhece que, de fato, Bolívia e Venezuela trazem dois modelos e muitas perspectivas. A respeito de ambos, identifica-se a origem em ancestralidades, assim como o protagonismo da comunidade enquanto sujeito coletivo. Entretanto, é mais acentuado, na Bolívia, o caráter da autodeterminação, do pluralismo político-jurídico e a reivindicação da autonomia enquanto pressuposto para o livre exercício de tradições, culturas e racionalidades. Um projeto elaborado e conquistado pela luta dos povos indígenas, para o qual, a ocupação de espaços na institucionalidade oficial - Estado -, parece ser um meio para assegurar a manutenção. A Venezuela, por outro lado, parece ser palco de um processo político que também envolve as bases sociais, mas sem alcançar entre essas o mesmo grau de consenso e engajamento popular que se viu na Bolívia. Como consequência, o governo assume o protagonismo na execução do projeto no país e, utilizando os aparatos estatais - referendos e processos legislativos, por exemplo - empenha-se em cumpri-lo. Além disso, as comunas venezuelanas parecem ter mais relação com o projeto de ocupação e democratização efetiva das instituições estatais e processos políticos, do que constituir um meio para assegurar o direito às tradições e racionalidades ancestrais, embora seguramente também o seja. É o elemento "identidade cultural" que parece reverberar muito mais nas reivindicações bolivianas.

Naturalmente o amadurecimento reflexivo pode alterar essas impressões, mas de qualquer modo, a derrota no referendo realizado em 2007 na Venezuela mostrou a importância da ampliação do consenso popular. Também reforça essa percepção o fato de que, enquanto na Venezuela até mesmo setores populares se viram divididos quanto ao projeto democrático de caráter comunitário, na Bolívia os mesmos setores seguiram firmes, inclusive quando enfrentaram violenta 
repressão estatal e resistência burguesa, provocando mais que uma reforma, uma profunda transformação na ordem e cultura constitucional. Então há matizes importantes distinguindo os dois processos, mas essas peculiaridades estão entre elementos comuns: a inspiração mais longínqua - as origens pré-coloniais incaica, maia entre outras - e os desafios externos - a resistência das elites nacionais e estrangeiras. $E$ as elites nacionais resistem porque se veem mais contempladas no projeto civilizatório da modernidade, do que na sua própria história e cultura.

A democracia na modernidade ocidental tem como ponto de partida e horizonte compreensivo uma tradição específica, particular, portanto, culturalmente determinada, ainda que tal relação seja dissimulada. Já para as tradições encobertas, a descolonização da cultura jurídica é fundamental, pois a emergência e afirmação de epistemologias periféricas é condição fundamental para pôr fim à marginalização e criminalização dessas tradições. Daí a importância em se evidenciar as influências concretas sobre ditos "modelos universais". Nesse sentido, a questão dos direitos culturais tem, entre os povos do Sul, um sentido que provavelmente não alcançará entre os povos do Norte. Porque no Sul, o desenvolvimento e transmissão da cultura e todos os seus sistemas demandou luta e resistência e assim vem sendo há cinco séculos, imprimindo nos povos o ideal que foi a mola propulsora das transformações políticas nas últimas décadas na América Latina. Ou melhor, na Abya Yala. 


\section{Referências}

ABBAGNANO, Nicola. Dicionário de Filosofia. 5 ed. São Paulo: Martins Fontes, 2007.

ALMARAZ, Patricia. Las Tierras Comunitarias de Origen, son un instrumento para recuperar el derecho sobre sus tierras. La Paz, 2005. Disponível em: http://www.eco minga.uqam.ca/PDF/BIBLIOGRAPHIE/GUIDE_LECTURE_6/5/4.Almaraz.pdf . Acesso em: 6 out. 2018.

AZZELLINI, Darío. Participación y poder popular: Conselhos Comunais y Comunas. In: VALERO, Jorge (comp.). Democracias nuevas o restauradas: el caso Venezuela. Caracas: El perro y la rana, 2012. pp. 117-132.

BASCOPÉ SANJINES, Iván. Consulta previa: un reto de democracia comunitaria. In:SANTOS, Boaventura de Sousa; EXENI RODRÍGUEZ, José Luis (org.). Justicia indígena, plurinacionalidad e interculturalidad en Bolívia. 2 ed. Quito: Fundación Rosa Luxemburgo, 2013. pp.381-406.

BAUDRILLARD, Jean. Simulacros e simulação. Lisboa: Relógio D'Água, 1991.

BOBBIO, Norberto. A teoria das formas de governo. 10 ed. Brasília: UNB, 1998.

BORON, Atilio A. Aristóteles em Macondo: notas sobre el fetichismo democrático em América Latina. Córdoba: Espartaco Córdoba, 2009.

BOLÍVIA. Ley $n^{\circ}$ 031, de 19 de julho de 2010. Ley Marco de Autonomías y Descentralización "Andrés Ibáñez". Disponível em: http://www.gacetaoficialde bolivia.gob.bo/edicions/view/154NEC. Acesso em: 6 out. 2018. 
BOLIVAR, Simon; BELLOTTO, Manoel Lelo; CORREA, Anna Maria Martinez. Simon Bolívar: política. São Paulo: Ática, 1983.

CÁRCERES, Florival. História da América. 2 ed. atual. e ampl. São Paulo: Moderna, 1992.

CÁRDENAS, Diego; ORTIZ, Luisa Fernanda; GONZÁLEZ, Germán Darío Rodríguez. Globalización y cultura jurídica: una mirada a dos tradiciones paradigmáticas. In: CÁRDENAS, Diego, et al. Aproximaciones a la cultura jurídica en Latinoamérica y Colombia. Bogotá: Universidad Nacional de Colombia, 2016. pp. 83-101.

CÁRDENAS, Diego. Recepción de la Cultura Jurídica en Latinoamérica. In: CÁRDENAS, Diego, et al. Aproximaciones a la cultura jurídica en Latinoamérica y Colombia. Bogotá: Universidad Nacional de Colombia, 2016. pp. 49-82.

CHÁVEZ, Hugo. Las comunas y las cinco frentes para la construcción del Socialismo. Aló Presidente Teórico n. 1. Caracas: Ministerio del Poder Popular para la Comunicación y la Información, 2009. Disponível em: http:// www.psuv.org.ve/wp-content/uploads / 2015/01/ Las-Comunas-y-cinco-frentes.pdf . Acesso em: 6 out. 2018. CHIVI VARGAS, Idón Moisés. Constitucionalismo Emancipatorio y Desarrollo Normativo: desafios de La Asamblea Legislativa Plurinacional. Texto Inédito. Bolívia, 2009.

CHUMACERO R., Juan Pablo (coord.) Informe 2010 Territorios Indígena Originario Campesino en Bolívia: Entre la Loma Santa y la Pachamama. Fundacion TIERRA: La Paz, 2011. Disponível em: http://ftierra.org/index.php/ publicacion/libro/2-informe-2010-territorios-indigena-originario-campesinos . Acesso em: 6 out. 2018. 
DUSSEL. Enrique. Oito ensaios sobre cultura latino-americana e libertação (1965-1991). São Paulo: Paulinas, 1997.

1492: o encobrimento do outro: a origem do mito da modernidade, conferências de Frankfurt. Petrópolis: Vozes, 1993.

Meditações anticartesianas sobre a origem do antidiscurso filosófico da modernidade. In: SANTOS, Boaventura de Sousa. MENESES, Maria Paula. Epistemologias do Sul. São Paulo: 2010. pp. 341-395.

Ética da Libertação: na idade da globalização e da exclusão. 4 ed. Petrópolis, RJ: Vozes, 2012.

EXENI RODRIGUES, José Luis. La largamarcha de las autonomías indígenas en Bolívia: demodiversidad plurinacional em ejercicio. In: SANTOS, Boaventura de Sousa; MENDES, José Manuel (eds.). Demodiversidad: imaginar nuevas possibilidades democráticas. México DF: Akal, 2017. p. 599-627.

FERNANDES, Leonardo. A Venezuela criada pela imprensa internacional. Brasil de Fato, 31 jul. 2017. Disponível em: https://www.brasildefato.com.br/2017/07/31/a-venezuela-criada-pela-imprensa-internacional/ . Acesso em: 6 out. 2018 .

FERRAZZO, Débora. Pluralismo jurídico e descolonização constitucional na América Latina. 2015. 462 p. Dissertação (Mestrado) - Universidade Federal de Santa Catarina, Centro de Ciências Jurídicas, Programa de Pós-Graduação em Direito, Florianópolis, 2015. Disponível em: http://tede. ufsc.br/teses/PDPC1180-D.pdf . Acesso em: 6 out. 2018.

GARCÍA LINERA, Álvaro. Democracia liberal vs. Democracia comunitária. In: WALSH, Catherine; GARCÍA LINERA, Álvaro; MIGNOLO, Walter. Interculturalidad, Descoloni- 
zación del Estado y del conocimiento. Buenos Aires: Del Signo, 2006. pp. 71-82.

GRAMSCI, Antonio. Cadernos do Cárcere. Vol. 2: Os intelectuais. O princípio educativo. Jornalismo. 2 ed. Rio de Janeiro: Civilização Brasileira, 2001. Disponível em: http://www. hlage.com.br/E-Books-Livros-PPS/Comunismo- Nazismo-Etc / Antonio \% 20Gramsci \% 20 - \% 20 Cadernos\%20do\%20c\%C3\%A1rcere\%20-\%20vol\%20II.pdf. Acesso em: 6 out. 2018.

GROSFOGUEL, Ramon. Para descolonizar os estudos de economia política e os estudos pós-coloniais: transmodernidade, pensamento de fronteira e colonialidade global. In: SANTOS, Boaventura de Sousa. MENESES, Maria Paula. Epistemologias do Sul. São Paulo: 2010. pp. 455-491.

GRUPPI, Luciano. Tudo começou com Maquiavel: as concepções de Estado em Marx, Engels, Lênin e Gramsci. 14. ed. Porto Alegre: L\&MP, 1996.

LEONEL JÚNIOR, Gladstone. A Constituição do Estado Plurinacional da Bolívia como um instrumento de hemonia de um projeto popular na América Latina. 2014. 345 f. Tese (Doutorado em Direito) - Faculdade de Direito, Universidade de Brasília, Brasília, 2014.

LOWY, Michael. Método dialético e teoria política. 4 ed. Rio de Janeiro: Paz e Terra, 1978.

LUDWIG, Celso Luiz. Para uma filosofia jurídica da libertação: paradigmas da filosofia da libertação e direito alternativo. Florianópolis: Conceito Editorial, 2006.

. Filosofia da Libertação, Crítica jurídica e Pluralismo: uma justificação filosófica descolonial. In: WOLKMER, Antonio Carlos; LIXA, Ivone Fernandes M. constituciona- 
lismo, descolonización y pluralismo jurídico em América Latina. Aguascalientes: CENEJUS, 2015. pp. 117-127.

MÉDICI, Alejandro. La constitución horizontal: teoría constitucional y giro decolonial. Aguascalientes/San Luis Potosí/San Cristóbal de Las Casas: Centro de Estudios Jurídicos y Sociales Mispat, A.C., Faculdad de Derecho de la Universidad Autónoma de San Luis Potosí, Educación para las Ciencias en Chiapas, A.C., 2012.

MENDES, Valdenésio Aduci. Democracia e participação: os Conselhos Comunais na Venezuela. Revista Sul-Americana de Ciência Política, v. 1, n. 1, 2013, pp. 14-32. Disponível em: https://periodicos.ufpel. edu.br/ojs2/index.php/rsulacp/article/view / 2309/ 2159 . Acesso em: 6 out. 2018.

PATZI, Félix. Tercer Sistema: modelo comunal: propuesta alternativa para salir del capitalismo y del socialismo. La Paz, 2013. Disponível em: https:/ / drive.google.com/file/ d/0Bz2t0ZGLPlmEdTdvNmxHVno1U3M/view . Acesso em: 6 out. 2018 .

PRZEWORSKI, Adam, CHEIBUB, José Antônio and LIMONGI, Fernando. Democracia e cultura: uma visão não culturalista. Lua Nova, 2003, no.58, p.9-35. Disponível em: www. scielo.br/pdf/ln/n58/a03n58.pdf . Acesso em: 6 out. 2018. SANTOS, Boaventura de Sousa. Pela Mão de Alice: o social e o político na pós-modernidade. 3 ed. São Paulo: Cortez, 1997.

SCHARFENBERG, Ewald. Constituinte de Maduro derruba procuradora-geral na Venezuela. El País, 5 ago. 2017. Disponível em: https:/ / brasil.elpais.com/brasil/2017/08/05/ internacional/1501933406_819134.html . Acesso em 6 ago. 2017. 
SILVA, Mayra Goulart da. O experimento comunal na Venezuela: entre a democracia direta e o hiperpresidencialismo. Revista de Estudos Internacionais (REI), v. 6, n. 2, 2015. pp. 6-27 Disponível em: http://www.revistadeestudosinternacionais.com/uepb/index.php/rei/article/ view/215/pdf . Acesso em 26 jul. 2017.

TORRE RANGEL, Jesus Antonio de la. Derecho y liberación: pluralismo jurídico y movimientos sociales. Bolívia, Cochabamba: Editorial Verbo Divino, 2010.

. Filosofia de la liberación y derecho: distintas perspectivas críticas de lo jurídico. Caleidoscopio. Aguascalientes, ano 5, n. 10. Jul./dec. 2001. pp. 175-199.

VEGA CAMACHO, Oscar. Transformaciones, descolonización y comunidades. In: Democracia, Participación y socialismo: Bolivia, Ecuador, Venezuela. LANG, Mirian; SANTILLA, Alejandra (compiladoras). Fundación Rosa Luxenburgo, Oficina Región Andina: Quito, 2010b. pp. 8793. Disponível em: http:// www.rosalux.de/fileadmin/rls_ uploads/pdfs/Themen/Ausland/Lateinamerika/AKLA/ democracia-participacion-y-socialismo-bolivia-ecuador-venezuela.pdf. Acesso em: 6 out. 2018.

WALSH, Catherine. Interculturalidad y (de)colonialidad: perspectivas críticas y políticas. Visão Global. Joaçaba, v. 15, n. 1-2, jan./dez. 2012. pp. 61-74. Disponível em: http://editora.unoesc.edu.br/index.php/ visaoglobal/ article/view/3412. Acesso em: 6 out. 2018.

WEFFORT, Francisco (org.). Os clássicos da política. 14. Ed. São Paulo: Ática, 2011.

WOLKMER, Antonio Carlos. Pluralismo jurídico: fundamentos de uma nova cultura no Direito. 4 ed. rev. e ampliada. São Paulo: Saraiva, 2015. 
WOLKMER, Antonio Carlos; FERRAZZO, Débora. Resignificação do conceito de democracia a partir de direitos plurais e comunitários latino-americanos. Revista de Direitos Fundamentais e Democracia, Curitiba, v. 16, n. 16, p. 200228, julho/ dezembro de 2014. Disponível em: http:/ / revistaeletronicardfd.unibrasil.com.br/ . Acesso em: 6 out. 2018. WOLKMER, Antonio Carlos; ORIO, Luís Henrique. Pluralismo jurídico e organização comunal: democracia e autonomia no constitucionalismo venezuelano. In: WOLKMER, Antonio Carlos; OLIVEIRA, Frederico Antonio Lima de; BACELAR, Jeferson Antonio Fernandes. Direito à diferença e constitucionalismo latino-americano. Rio de Janeiro: Lumen Juris, 2017. pp. 35-68.

WOLKMER, Antonio Carlos. MELO, Milena Petters. Constitucionalismo latino-americano: tendências contemporâneas. Curitiba: Juruá, 2013.

WOLKMER, Antônio Carlos. Ideologia, estado e direito. 4 ed. São Paulo: Revista dos Tribunais, 2003.

ZEGADA C., María Teresa. Bolívia: la democracia intercultural como sínteses de las diferencias. In:SANTOS, Boaventura de Sousa; MENDES, José Manuel (eds.). Demodiversidad: imaginar nuevas possibilidades democráticas. México DF: Akal, 2017. pp. 571-597. 
Recebido em 06/10/2018

Aprovado em 06/11/2019

\section{Antonio Carlos Wolkmer}

E-mail: acwolkmer@gmail.com

Débora Ferrazzo

E-mail:dferrazzo@hotmail.com 
